\title{
Sri Lanka: State of Research on Democracy
}

\author{
Jayadeva Uyangoda
}

\section{Introduction}

In Sri Lanka's political science research, the body of work directly on the theme of democracy is somewhat thin. The survey and studies on the 'State of Democracy and Human Security", carried out by the Social Scientists' Association (SSA) in 2004-2005 is the main research effort made directly in the field of democracy studies. This was a part of a larger South Asian study. The report on the State of Democracy in South Asia is now published by the Oxford University Press, India. Nevertheless, in the wide body of scholarly literature on political and social change in the postcolonial Sri Lanka written by political scientists, historians, sociologists and anthropologists, themes with direct relevance to democracy studies have constituted a subject of continuing interest.

This paper has two main parts. In the first part, it presents a survey of the major themes that have constituted the broadly social science research that are useful to place the problematic of democracy in a new research agenda. In the second, the paper suggests a few possible areas of new research on the theme of democracy.

Before proceeding to the survey of the literature, it is useful to identify the key aspects of the problematic of democracy in Sri Lanka. The nature of Sri Lanka's democracy problematic is that institutions of electoral and parliamentary democracy continue to exist with only minor deviations along with a continuing civil war and amidst violence. Since the early 1970s, politics in Sri Lanka has been taking place at two levels -first at the level of legal, electoral and parliamentary practices and second, as counter-state mobilization, armed rebellion and counter-insurgency war. Institutions of parliamentary democracy appear to have taken firm roots in the Sri Lankan society, as characterized by a comparatively long institutional history of modern democracy, high level of electoral participation, penetration of the political party system into all corners 
of the society, and the regular and peaceful change of regimes by means of elections. However, Sri Lanka has also produced twin counter-state insurgencies - one in the majority Sinhalese society and the other in the minority Tamil society. The concentration of the civil war process since the 1970s demonstrates a particular co-existence between two seemingly contradictory processes, parliamentary democracy and anti-state rebellions. The prevalence of counter-state insurgencies indicates that Sri Lanka's democracy has had some serious limitations in addressing the substantial social and ethnic grievances. But, these systemic challenges do not yet seem to have precipitated any serious democracy reform endeavor. Exploring this 'democracy problematic' is the task of a larger exercise of interpreting and understanding Sri Lanka's contemporary political and social change.

It is important to note at the beginning that a survey of literature on a broad theme as democracy is a challenging task due to a number of reasons. First, although it is important to avoid the arbitrary practice of imposing disciplinary boundaries on the literature, connecting the literature through the vague notion of democracy is an intensely arbitrary exercise. Second, the review works within the logic of exclusion and inclusion. The literature included and the literature excluded in this review should not make any claim to the presence or absence of scholarly merit. The literature excluded is also present in this essay through their thematic relevance to strands of thought, research and inquiry discussed in the course of the review.

\section{The Question of 'Nation-Building' and Democracy}

The story of Sri Lanka's post-colonial political change has been characterized by the production and re-production of conflictual ethnic relations, interspersed with minority demands for regional autonomy. This process eventually led to a civil war for secession. There were some key events and developments that defined this process of change. The rise of post-colonial Sinhalese and Tamil ethnic nationalisms, the emergence of identity-based political mobilization, political awakening of non-elite and non-dominant social and ethnic groups, and the pressure exercised by those non-elite social strata in the domain of public policy were particularly significant developments occurred in the first decade of political independence of 1948. Among the key events that re-shaped the nature of Sri Lanka's post-colonial state, state-society relations and indeed inter-ethnic relations was the regime change of 1956 which brought the post-colonial Sinhalese nationalist forces to the domain of state power. Subsequently, two events of ethnic violence, first in 1958 and then in 1983, further re-defined the relationship between the post-colonial Sri Lankan state and the Tamil ethnic minority in a framework of mistrust, confrontation and conflict. The eventual rise and spread of the minority Tamil armed struggle marked the culmination of a process of change from relative social peace to a protracted phase of ethnic violence and civil war. 
Even the first ten years of independence brought into focus how Sri Lanka was undergoing a rapid process of transition. The transition was taking place in a number of key areas. The social bases of the political elites were being widened to incorporate secondary and 'vernacular' elites who have been earlier excluded from the domain of state power. The ethnic mobilization was undermining the idea of unity on which the foundations for the new state were laid. Electoral politics with mass participation and appeal was beginning to produce more divisive consequences for the political order. Scholarly work on Sri Lanka's political process in early post-independence years has responded to these crisis events and processes in varying ways. In an early attempt to understand the rapidity with which post-colonial Sri Lanka had to grapple with the challenge of just being a modern nation-state, Wriggins inaugurated the 'dilemmas of nation-building' perspective (Wriggins: 1960). In Wriggins' argument, the 'new nations', in their formative years of post- independence, came to be confronted with the problem of 'national disunity' rather than unity. Electoral politics and democratic competition did not provide adequate space for peaceful negotiation of 'pluralistic, communal differences,' but only accentuated the already existing divisions while sharpening intergroup antagonisms. It needs to be noted that Wriggins' study covered the first ten years of post-colonial nation and state formation in Sri Lanka. Among the "fundamental problems" (Wriggins, 1960:7) that dominated the politics of the "new nation" of Ceylon were (a) the role of religious institutions, religious revival and cultural nationalism in public life, (b) the goals of national unity in a backdrop still marked by "traditional ethnic and linguistic differences," (c) efforts to achieve an adequate rate of economic development, and (d) the practice of democratic elections as a peaceful means to change or affirm political leadership. For Wriggins, these were not challenges unique to Ceylon. They were shared by many other 'new nations' as well. But, the account which Wriggins gave on the politics of first ten years of independence in Sri Lanka pointed to the formidable dilemma that a post-colonial democracy faced in forging national unity and political stability within a broad framework of liberal democratic governance. Wriggins seemed to suggest that ethnic mobilization in a zero-sum perspective was integral to the kind of political struggles that democracy engendered in post-colonial Sri Lanka. The worry about the illiberal consequences of such ethnic politics in a polity with limited economic resources and cultural space for compromise is the sub-text of the 'dilemmas' that Wriggins mapped out throughout his book.

Many scholars have followed this 'nation-building' perspective to state Sri Lanka's story of the growth and spread of majoritarian and minoritarian ethnic politics (Kearney: 1967, Jupp 1978, Phadnis: 1989). Kearney's work in the 1960s on the role of 'language politics' (Kearney: 1967) in sharpening the antagonisms between the two main ethnic communities and Phadnis's work (1976) on Buddhist nationalism and its sway over the democratic process are two key examples of the culturalist explanation 
of the political challenges of nation-building. This "problems of nationbuilding' approach was quite dominant in the political science research in the 1970s. One major assumption in this 'nation-building failure' literature is that the pluralistic divisions in society had both fostered and obstructed the emergence and consolidation of democratic government. Phadnis, in her contribution to the volume on 'Democracy in Asia' argued how ethnic mobilization had brought 'severe strains and stresses' on the 'democratic system' pushing the country into the "throes of crises of legitimacy and integration" (Phadnis, 1989:145). Wilson, a Sri Lankan political scientist of the first generation, has produced a considerable body of literature broadly within the nation-building perspective, focusing much on the constitutional and institutional aspects of political change (Wilson: 1974 and 1975). Wilson, himself a member of the Tamil minority community, seems to have maintained a long-standing faith in the efficacy of the liberal democratic institutions in managing Sri Lanka's majority-minority relations. That faith could not survive the 1983 violence and the subsequent civil war. His later writings reflected that loss of faith in majoritarian liberal democracy and he even used the metaphor of the 'breaking up' of Sri Lanka as a nationstate to suggest a possible trajectory for Sri Lanka (1988 and 1994).

Quite interestingly, the nation-building and national integration framework of political understanding enjoys a long life in Sri Lanka. It has become a part of the official political discourse since the mid-1990s. 'Liberal' intellectuals too deployed this concept during this period - for example, Tiruchelvam (2000) - in a context where there was the need for a serious alternative to the Sinhalese majoritarian project of the state and nation building. The official ideology of the People's Alliance (PA) regime in 1994-1995 was one that emphasized pluralistic and multicultural nation-building through political negotiations with the LTTE and constitutional reforms aimed at restructuring the existing Sri Lankan state in a framework of power-sharing, as opposed to constitutional unitarism. Thus, the discourse of nation-building in the second half of the 1990s had a state-reformist agenda, although its vision and prospects may have been somewhat limited. In fact, the PA government established a 'Ministry of National Integration' in 1994 and the Minister in charge of the subject of national integration was the Minister of Constitutional Affairs. Even at present there is a Ministry of Constitutional Affairs and National Integration. This coupling of 'national integration' with constitutional affairs suggests the primacy accorded in the official thinking to institutional designing for national integration' In this exercise of what one may call nation 'rebuilding', the Norwegian government assisted the Sri Lankan government in the mid-nineties to set up and operate a National Integration Programme Unit. Among its functions are research, training, capacity building and advocacy in a new vision for national integration. A most recent publication by this Unit acknowledges that bringing about "sustainable ethnic harmony" through "national integration" in a society that has gone through a protracted civil war was both "difficult and complex" (Jayawardane, 2007: 1). 
Parallel to the literature on the failure of nation-building and national integration has been an extensive body of work on the theme which may be called ideological barriers to accommodation." Accommodation in this literature means mutual adjustments that the majority and minority communities were expected to make in recognizing each other as rightsbearing communities of equal status in a democratic polity. The focus of this genre of literature is on the role of Sinhalese and Tamil ethnonationalist ideologies in preventing democratic accommodation by failing to invent new pluralistic political institutions. Roberts in his 1978 essay brought to the fore the centrality of ideology for this analysis. He made the argument that longstanding group identities and prejudices, a bipolar demographic structure that favoured the majority Sinhalese community in electoral competition, and the historical legacies as well as ideological constellations that occurred immediately after political independence had played a crucial part in creating insurmountable barriers to democratic accommodation (Roberts: 1978). The volume that Roberts edited in 1979, Collective Identities, Nationalisms and Protest in Modern Sri Lanka, had a host of chapters by scholars working on Sri Lanka on the ethno-identity politics and its cultural and political consequences. This volume was a major initiative in the culturalist interpretation of competing nationalist politics in Sri Lanka. It needs to be noted that the culturalist interpretation of the ethnic conflict in Sri Lanka continues to command respect among anthropologists, sociologists and public opinion makers.

The ideological, or culturalist, dimensions of the Sinhalese nationalist project of nation-building are to a considerable measure shaped by the political mobilization of Buddhist communities, notably the Buddhist monks. The story of Sri Lanka's post-colonial democratization remains incomplete if it does not include the chapter on Buddhist political involvement which first emerged in the immediate post-independence years as a social movement autonomous of party politics. Subsequently, politically mobilized Buddhist constituencies joined the mainstream political parties, influenced regime formation and eventually exercised power over governments over issues of public policy. How did Buddhist monks come to acquire such a position as a decisive stakeholder in Sri Lanka's post-colonial politics? How did the Sri Lankan society manage to produce politically assertive religious - Buddhist, in this case constituencies? What does the Buddhist political mobilization mean for Sri Lanka's democracy? Answers to questions like these are mostly attempted in the anthropological literature on Sri Lanka, and not always in the political science work.

The key literature dealing with interventions by Buddhist communities in Sri Lankan politics are Phadnis (1976), Obeyesekere (1970 and 1995), Tambiah (1986 and 1992), Kapferer (1983 and 1988), Seneviratne (1999), and Abeysekere (2004)). These studies have grappled with, from a variety of perspectives, some key dilemmas of the post-colonial democratic political change in Sri Lanka. For example, Phadnis (1976) 
provides an extensive account of the political mobilization of Buddhist monks (the Sangha) in the 1950s outside the established political parties as well as the state, and within an autonomous social space, or, to use a contemporary expression, as a civil society movement of resistance to elite domination. Obeyesekere in an extensive body of work (for example 1970, 1995) explored the way in which Buddhism in Sri Lanka negotiated with colonial and post-colonial modernity, producing what he calls 'Protestant Buddhism,' a peculiarly urban, middle-class and intellectual Buddhism that had developed political ambitions through ethno-nationalist claims. Tambiah $(1986,1992)$ takes this analysis further to argue that the ethnically politicized Buddhism has emerged as the dominant ideology and ontology in Sinhalese society, producing a radically militant approach to politics that views ethnic and religious minorities both as a threat to the ethnoreligious majority and deserving a secondary and subordinate position in the ethnic hierarchy. Seneviratne (1999) shows how the politicization of Buddhist monks has led to a particularly conservative practice of Sinhalese nationalism that has acted as an obstacle to political-structural reform. Kapferer's work $(1983,1988)$ exclusively focuses on explaining the legitimating of violence in social, cultural and political practices in Sinhalese society.

Consequences of exclusivist ethnic imaginations in shaping the struggle for state power in a bipolar framework is the theme RajasinghamSenanayake (1999) has developed in trying to understand the links between the state and identity politics in Sri Lanka. The argument in this paper is that the bipolar framework of ethnic imagination has brought Sinhalese and Tamil competition and conflict to a position of dominance in the struggle for state formation, with the result that other forms and spaces of democratic struggles were obliterated. It needs to be noted that the rise of ethnic mobilization and the spread of the ethno-political civil war in Sri Lanka has paralleled with the decline of the working class and trade union struggles. Gunasinghe has described this displacement of class politics by ethnic conflict as "ethnic over-determination." (Gunasinghe, 2001).

Nationalism and violence continue to be the themes of analysis in political anthropology of Sri Lanka. Kapferer (1983, 1988), Obeyesekere (1984), and Spencer (1990a, 1990b, 2007) were among the pioneers in this discussion. Later Tambiah (1992) made a substantial contribution in exploring the link between Buddhism and nationalist politics in Sri Lanka. The circumstances under which the anthropological inquiry turned to the explicitly political problematic of nationalism and political violence were conditioned by the ethnic violence of 1983. It seems that these anthropologists just happened to be there in Sri Lanka doing their regular, 'conventional' field work when the ethnic violence broke out in July 1983. Kapferer was studying sorcery and rituals in the rural Sinhalese society in the Southern province. Spencer was engaged in a village study in the Sabaragamuwa province in the lower central part of the Island. Obeyesekere's research by this time was on changes in Buddhist religious 
practices in response to social transformation. The violence in 1983 seems to have shifted this conventional focus of anthropological inquiry in Sri Lanka to issues of nationalism, political conflict and collective violence. In his work in the 1980s, especially against the backdrop of violence against the Tamils, Kapferer argued that there was a specific 'ontology' of violence that is embedded in Sinhalese nationalist ideology and its practices, which treats the Tamils and minorities as 'demons.' In this analysis, outbreak of collective ethnic violence has a cultural analogy and legitimation in folk rituals (Kapferer: 1983 and 1988). Kapferer has also been challenged for this particular reading of group violence (Spencer: 1990b, Scott: 1992, 1994) on the premise that he has essentialized rural cultural practices into an 'ontology' ignoring how political violence is produced and reproduced in specific political conjunctures and under specific conditions of political crisis.. Although a few anthropologists have repeatedly grappled with the theme of collective violence in Sri Lanka, political science inquiry has not focused much on any major aspects of political violence in a systematic research programme. Samaranayake's work remains the main body of studies on political violence in Sri Lanka's Sinhalese society within the discipline of political science. ( Samaranayake: 2008). Yet his work deals with mainly on the radical, insurrectionary politics of the JVP. Among the major work on violence in Tamil nationalist/identity politics are HellmannRajanayagam (1994) and Manogaran and Pfaffenberger (1994).

Quite apart from these debates on explaining violence in Sri Lanka as a social and cultural practice, political violence does constitute a major concern in the political sphere. The trajectory of political violence in Sri Lanka has moved along a few notable directions. In the 1950s it was state violence against an ethnic minority. The early 1970s marked the beginning of counter-state political violence in the form of radical resistance. The politics of radical resistance and counter-state violence also generated counter-insurgency violence of the state. Meanwhile, the early 1980s saw the resurgence of violence between the state and the minority Tamil ethnic community. This was a new development that led to a process of protracted civil war from which Sri Lanka has not yet been able to detach itself. In the continuing civil war, there have also been multiple processes of militarization in society. The state has been thoroughly militarized. So is counter-state politics. Some of the political science work that examines political violence in this period are Senaratne(1997) and Uyangoda (1996). Inter-ethnic group relations, particularly among the Tamils and Muslims, are marked by regular outbreaks of violence. Amidst the protracted war, the military approach to political problems has been privileged as the most effective means to protect the existing state as well as to create a new state form. In this context, one crucial question that still remains unexplored in the scholarly literature is how the nearly three decades of generalized political violence has impacted on Sri Lanka's democratic process. Clearly, the civil war and unresolved conflicts have not obliterated democratic governance. Democracy seems to co-exist with war and violence through 
some significant adjustments and compromises. The articulation of democracy and violence is a key area to be explored in future research.

\section{Explaining Authoritarian Political Trends}

One characteristic feature of the politics of Sri Lanka that became prominent in the 1980s and the 1990s is the shift towards authoritarianism. This tendency occurred along two main trajectories. The first was the shift towards concentrating state power in the executive branch of the state and the displacement of the legislature in the process of decision making and public policy. This shift occurred through constitutional means, its primary manifestation being the constitutional change of 1978 which created a powerful office the Executive President. Imposition of limits on trade unions, oppositionist politics and the rule by repressive legislation were other manifestations of this constitutional drift towards authoritarianism. The second trajectory was the militarization of the ethic conflict. It meant that the government resorted to war and violence as the preferred strategy of managing the ethnic conflict and majority-minority relations. Some scholars have explained the authoritarianism in the 1970s and 1980s in terms of the weakness of the Sinhalese ruling bourgeoisie to deal with pressures coming from the electorate, the elected representatives as well as the legislature (Jayasekara and Amarasinghe: 1987). Some other scholars have explored the logic of dependent capitalism in crisis (Ponnambalam: 1981, Gunasinghe: 2001). DeVotta: (2002, 2003, 2004 and 2006) sees a link between ethnic outbidding, inter-party feuding and 'political decay' in producing Sinhalese ethnic majoritarianism as well as political authoritarianism. In DeVotta's argument, majoritarian ethnocentric practices, developed in a continuing process of ethnic outbidding among the Sinhalese political parties and leaders, contributed to a larger process of 'political decay and illiberal governance.' Major characteristics of Sri Lanka's illiberal governance, according to DeVotta, included the absence of free and fair elections and the rule of law as well as basic political freedoms. The state failure in ethnic accommodation giving way to 'ethnic superordination and violence.' Was its overall outcome.

The political economy of counter-democratic tendencies in Sri Lanka's recent politics has been an interesting area of research that has emerged in the post-1977 era of economic liberalization. Sri Lanka is the first South Asian country to move away from the statist development model and embrace liberalization. This major policy shift occurred with the regime change in 1977. The United National Party (UNP), with a rightwing social and economic agenda, formed the government with a fivesixth majority in parliament. The UNP regime 'liberalized' the economy, but maintained a tight control over the political and governance processes that included frontal assaults on the trade unions, restrictions on civil liberties and attacks on the opposition political parties. Is there a link between economic liberalization and political authoritarianism in the post1977 period in Sri Lanka? Is it economic liberalization that necessitated 
illiberal politics? The popular and political assessment of the politics of Sri Lanka's economic liberalization is that in order to implement a potentially de-stabilizing 'liberal' economic reform programme, the UNP regime of 1977 deliberately opted for an authoritarian constitutional and political framework. Some scholars have questioned this view that seeks a direct link between economic liberalization and political authoritarianism. For example, Moore $(1990,1992)$ concludes that there is a very little empirical evidence to show a causal connection between economic liberalization and 'political decay.' The post-1977 authoritarianism, in Moore's argument, was a part of a "multidimensional process" of 'political decay' that had set in prior to 1977 . Therefore, the main causes of political decay should be seen "within the Sri Lankan political system itself" and they are "not to be found within the sphere of economy" (Moore, 1990:345-346).

\section{Social Bases of Political Power, Patronage and Clientalism}

The body of literature on the social bases of political power, political clientalism and the working of democracy in patron-client settings in Sri Lanka has not been particularly strong. There is hardly any recent work on these issues although patronage and clientalism appear to have reached new heights in a backdrop characterized by unstable parliamentary majorities, regime formation through coalition politics and economic liberalization.

Meanwhile, one of the most fascinating aspects of electoral politics in Sri Lanka is the continuing re-activation of caste as an organizing principle in the actually existing democracy. How does the democratic political process work within a social formation that is characterized by caste divisions, domination, marginalization and competition? Anthropological studies on caste in both Sinhalese and Tamil societies are quite rich (Leach: 1961, Mcgilvary: 1982, Obeysekere: 1967, Peiris: 1956, Ryan: 1953, Spencer; 1990, Stirrat: 1982, Yalman: 1967, Pfaffenberger: 1982). The early anthropological and sociological studies on caste in Sri Lanka, even up to the 1970s, focused on themes like kinship, family, social stratification, land tenure, rituals and the rural division of labour. The interaction between caste and politics, focusing on questions like what has the democratic process done to caste relations in local settings, or how does electoral mobilization negotiate with caste loyalties and networks, have not been in the research agenda of this early anthropology/sociology literature on Sri Lanka. In contrast, the anthropological literature in the 1980 s and after on Sri Lanka's rural society is quite useful to understand the way in which politics works on the ground level, in relation to caste and other social bases of political power.

One of the key publications that foregrounded caste as a social category in understanding Sri Lanka's democratic politics was Jiggins' work, Caste and Family in the Politics of the Sinhalese, 1941-1976 (1979). Jiggins was the fist political scientist to examine the relationship between caste and politics in Sri Lanka. Although caste had always been a key 
feature in Sri Lanka's electoral mobilization, voter choices, the selection of candidates and even in the appointments to Cabinet positions, rarely has this dimension of actually existing democracy in Sri Lanka been publicly acknowledged or subjected to academic research. In the discourse of anthropology, caste has been a dimension in the private sphere of the rural society, but never an element of 'national life.' Jiggins' work in a way broke this myth and for the first time demonstrated how caste and family have been key variables in the democratic political competition. This book focused on how caste and family interacted with "modern political ideologies, parties and platforms and their role within a parliamentary system" (Jiggins, 1979). It commented on the relationship between the social structure and the political parties, patron-client relationships at local and national levels, family and lineage networks among the political elites, and the vertical relationship between the political elites and the rural masses.

Robinson's Changing Sinhalese Village (1975), Hettige's Wealth, Power and Prestige (1984), Spencer's A Sinhalese Village (1990), and Gunasekera's Hierarchy and Egalitarianism (1994) are helpful to understand the social bases of political power in the Sinhalese rural society as well as the dynamics that bring the 'national' politics to the village which in turn appropriates, internalizes and relates to national political agendas.

Hettige's study of Sinhalese village in Sri Lanka's North-Central province in the late 1970s is about the transformation of "a small peasant hamlet substantially isolated from the centres of power during the early British period" into "highly diversified agrarian structure" characterized by the presence of commercial farming, wage labour and migrant labour. In chapter Five, his focus is on the changing forms, patterns and dynamics of power and authority relations and how they are manifested in local-level politics. Hettige links the changes in village level politics to the processes of regional and national level politics. What is interesting in this study is the way in which a new power and authority structures have emerged, both at formal and informal levels. With the changes in the state structure at the national level, a new bureaucratic structure has developed, with links to the national political structures. In parallel, there is also an informal structure of power associated with political parties. There are now new leaders and 'influentials' emerged in the village setting, whom Hettige calls 'modern political leaders.' These new leaders are popular political figures who are also agents of national political parties. The influentials are primarily those with economic power, who have acquired a capacity to intervene in village affairs. The fact that a majority of villagers is poor and powerless gives the new leaders and influentials a certain prominence. There are also new patronage relationships that constitute a crucial link between the village and the external world. But the extent of patronage is limited because of the relative paucity of resources available. The village is also now factionalized along political lines, and these factions have emerged in a close relationship with national political competition. The 
crucial point that Hettige makes is that 'village politics' is integrally linked to 'national' politics through a variety of linkages.

Spencer's book is based on fieldwork conducted in a rural Sinhalese village in the Sabaragamuwa province in 1982-83 when a country-wide political crisis erupted in the form of anti-Tamil ethnic violence. In that moment of generalized ethnic violence, politics of this village was not an isolated occurrence, but a part of the heightened nationalist politics marked by the ethnic violence of July 1983. Sri Lanka's rural politics for most of the post-independence years has been shaped by the state as the distributor of material resources and through the politics and ideology of welfarism. The ideology and symbolism of Sinhalese Buddhist hegemony is the other ideological feature that shaped rural politics. Spencer identifies a third feature, "the embeddedness of politics in everyday life" (Spencer, 1990:259). In the latter, "public party politics" has provided the villagers with an idiom to negotiate private grievances. In Spencer's story of the village and its politics, politics envelopes entire everyday life of the village who engages in it with "consummate passion." (208).

Gunasekera's work Hierarchy and Egalitarianism in a Sinhalese village makes the interesting point that a radical change has occurred not in the caste and class hierarchies in rural society, but in the "hierarchy of power" (1994:224). The transition to independence as well as the development of democracy and political party system has, according to Gunasekera, "fundamentally altered the structures of local-level power." Community power structures are now established around the Members of Parliament, creating an 'MP's Raj.' Political backing has superseded wealth and caste. Gunasekera even asserts that there has developed a "comprehensive rejection of hierarchy" in the dimension of power. But there is a paradox in the village setting. The development of democracy has not created space for the local political leadership to emerge from the community itself. The rural power elite is corrupt. It does not command respect or allegiance of the villagers. The party political basis of their power denies the new local power elite "the ability to acquire the qualities of leadership." Similarly, the authority of the local power elite, integrally linked to political parties, is also conditional to which party is in power at national level. Periodic changes in the national and regional power structures that occur in relation to national elections render their tenure of power "essentially temporary" (p. 195). In Gunasekera's analysis, there is an interesting dialectic between the spread of democracy and the demise of rural political leadership. The impact of democracy has denied the new power elite "the qualifications of leadership;" it has also fostered egalitarian ideologies that have ensured "the demise of followers" as well. What a thing for democracy to do in the rural Sinhalese society!

What is the most important variable in shaping electoral politics in the rural Sri Lankan society, caste relations or patron-client networks? Political scientists seem to be divided on this issue. Jiggins (1979), for example, argued for the primacy of caste factor in deciding electoral 
outcomes. Jayantha (1992) has challenged this thesis arguing that more than caste, patronage networks were the key to explaining political allegiance in Sri Lanka. Jayantha makes the claim that according to his case studies, "the patronage network was the fundamental explanatory variable, and that where it cut across the caste tie, it was decisive" (1992:206). Both Jiggins and Jayantha did their studies much before the real working of the Proportional Representation (PR) system, with its system of candidate lists and preferential voting, became clear. Anecdotal accounts of the way in which the PR system now works in national, provincial and local elections indicate that caste allegiance and appeal has assumed a new significance. New research can certainly map out the relative roles of both the caste and patronage dimensions of electoral politics; yet it is possible to hypothesize that both have inter-penetrated, producing a new sociology of electoral politics.

\section{Limits of Democracy in a Majoritarian Political Process}

One of the most extensive areas of scholarly work on contemporary Sri Lanka's politics is in relation to the question of how ethno-nationalist politics has pushed Sri Lanka's democratic politics into an illiberal, counterdemocratic trajectory. Political scientists and constitutional lawyers have been particularly active in examining the limits of Sri Lanka's post-colonial democracy in reforming the state within a framework of pluralism and multi-culturalism (Amaratunga: 1989, Coomaraswamy: 2003a, Edrisinha: 1993, Tiruchelvam: 2000, Uyangoda: 2001, Wickramaratne: 2007). This expanding body of literature has two defining characteristics. It presents a sustained critique of the unitarist constitutional model of the postindependence Sri Lankan state and its inability to reform itself in a pluralistic direction. The second feature is the advocacy of a commitment to political reform. This literature, with a self-consciously prescriptive character, advocates devolution, or federalism, to constitute the basic framework of the state along with a negotiated political settlement to the ethnic conflict.

In this literature of political reforms, there is a key theme that touches on the global democracy debate in relation to minority rights, multi-culturalism and the politics of recognition. The Sri Lankan debate is about how to accommodate 'ethnic demands' in a new democratic dispensation. The public debate has been very political. Three competing perspectives have emerged on this issue. Minority nationalists argue, although implicitly, for the primacy of 'group rights' over individual rights on the premise that the 'individual rights' perspective has been serving ethnic-majoritarian democracy. The primacy focus of this group-rights approach to political reforms is on constitutional arrangements for powersharing (Tiruchelvam: 2000, Wilson: 1988). Opposed to the group rights approach to political reforms is the conventional perspective of liberal constitutionalism which considers the group rights approach as essentially counter-democratic. It also argues for the adequacy of an individual 
rights framework to address democratic concerns inherent in minority grievances. In this view, the group rights approach will undermine the unitary nature of the existing Sri Lankan state. Constitutional lawyers representing the majority Sinhalese interests have been in the forefront in making this argument. A third perspective, which may be described as 'communitarian democratic,' argues that 'group rights' claims should be incorporated in democratic solutions to ethnic conflicts, because that is the only guarantee against majoritarianist abuse of the individual rights framework while being alert to counter-democratic possibilities of groups rights regimes (Uyangoda: 2007).

\section{Mediatory Institutions}

Institutional designs of the Sri Lankan state, as mentioned earlier, continue to receive considerable attention from political scientists and legal scholars, generating even debates on most suitable constitutional designs to reflect changing power relations among Sri Lanka's ethnic groups. However, studies on mediatory institutions of governance and institutional spaces for democratic mobilization and bargaining have received only insignificant scholarly attention in Sri Lanka. This is notwithstanding the fact that Sri Lanka's political party system, the trade union movement, the character and dynamics of social movements etc have undergone changes that can be described as fundamental.

Sri Lanka's political parties and trade unions have been extensively studied only in the 1960s and 1970s, and for some strange reason, political scientists have not continued their interest in the subsequent changes and dynamics in the party system. This is despite the fact that political parties, with the emergence of new ones, continue to be the dominant mediatory institution between the citizens and the state. Lersky's study on the Leftwing Lanka Sama Samaja Party (1964) is the first full-scale study on a political party in Sri Lanka. Lersky's focus has been primarily on providing a narrative history of the LSSP with descriptions on the party's origins, ideology, internal disputes and programmatic commitments. Woodward's (1969) work on the growth of the political party system in Sri Lanka is a 'political science' work in the disciplinary sense of the period. It gives an account of Sri Lanka's tendency towards a one-party system in the early 1950s, the emergence of a "competitive party system" in the mid1950 s, the subsequent consolidation of the political party system, and the development of "a two-party character" in a multi-party system. Although a large number of political parties have emerged, as Woodward argues, the essential feature of this system is its bi-polarity around two main political parties, the UNP and SLFP. This has been reflected in elections as well as regime formation after elections. What Woodward observed in the late 1960s as the bi-polar character of parliamentary elections is valid in relation to elections even in 2004: "Contrary to their multi-party appearance, elections in Ceylon are pre-eminently two-party contests" (Woodward,1969:249). Even the electorate associates political parties in a bi-party framework. 
Woodward also provides a detailed account of what he calls the "transformation" of Sri Lanka's party system. The first feature of this transformation is the transition through an initial phase of one-party dominance to a 'competitive' party system, and then to a 'dominant' twoparty system and its eventual consolidation. The second feature is the transformation of the social character of the party system. Woodward describes this as a process of "displacement of notables as viable and selfsufficient political units." While the parties have displaced the hegemony of notables, the parties themselves became, in Woodward's terms, "social parties" (1969:275), in the sense that parties came to respond to the voters in more "intimate association with the people." With this growing link between the parties and the voters, Woodward observes the development of a "responsible party system" which he sees as having been "essential to the viability of a parliamentary system in Ceylon," because it was through parties that "both the political elite and people were effectively related to parliament" (1969:287). In subsequent writings on Sri Lanka's political parties, Kearney (1973) and Jupp (1978) make more or less similar analysis inspired by the 'political development' perspective that remained dominant among political scientists working on South Asia. Kearney described Sri Lanka's party system as one of "competitive pluralism" because the party system was "not only competitive, but [also] highly pluralistic" (Kearney, 1973:97).

Despite the lack of interest among the political scientists, political parties in Sri Lanka have new contexts that have obviously re-defined their mediatory role in linking the citizens with the state. The first is the rise and spread of armed rebellions spearheaded by social and political movements that have emerged outside the formal political party framework. The Janatha Vimukthi Peramuna (JVP-People's Liberation Front) in the Sinhalese society, the Liberation Tigers of Tamil Eelam (LTTE) and a host of Tamil nationalist armed groups have in a way undermined the monopoly of the power of the state as well as the claims by mainstream political parties to 'represent' the people. In some instances, they have succeeded in weakening the political parties, 'banning' elections and unleashing violence against political parties and their cadres. Interestingly, the JVP after leading two unsuccessful armed rebellions against the state has now rehabilitated itself to emerge as the third largest parliamentary party. Several Tamil armed groups have also transformed themselves into political parties and they take part in elections, send their leaders to parliament and even to become cabinet ministers. Sri Lanka thus offers a fascinating political landscape of political parties and armed insurgent movements existing in antagonistic spaces. The situation of dual power in part of the Northern and Eastern provinces (Stokke: 2006) is a direct outcome of the unresolved and protracted contestation for state power between the government and the LTTE.

Meanwhile, a raging debate on the political role of NGOs has highlighted a new antagonistic relationship developing between political 
parties and NGOs on the question, who should, in what way, represent the citizens in the domains of interest articulation, social mobilization, and shaping public policy. The activism of independent social groups in the domains of social welfare as well as political and social mobilization has been a part of Sri Lanka's colonial modernity, even in the late nineteenth and early twentieth century. Sri Lanka's trade unions and political parties have historically evolved in the early and mid-twentieth century in a social space initially inhabited by such autonomous social groups. The 'problem' of NGOs as posed by nationalist political parties is linked to a situation in which the parties see NGOs as a source of threat to their ideological mobilization. This threat perception has been particularly acute in a context where some NGO's have been active in advocacy and intervention for minority rights and peace-building. The radical nationalist JVP is spearheading the argument that NGOs have no legitimate right to engage in politics because they are not representing, or accountable to, people as are the political parties. They also argue that these politically active NGOs, although they are elitist and unrepresentative, yet wield disproportionate degree of power in shaping public policy and regime agendas. There is an emerging body of academic literature on this controversy with the argument that NGOs represent either "new circles of power" (Wickramasinghe: 2001) linked to the global civil society as well as multi-lateral institutions. A particularly hostile characterization of NGOs is offered by some calling them agents of "re-colonization" (Gunathillake: 2006). But, this contestation poses some significant issues concerning democratic representation, the relationship between 'public democracy' and 'civic democracy' as well between political society and civil society.

\section{State Reform}

The question of the state has been at the center of violent political struggles in Sri Lanka since the 1970s. The two JVP uprisings of 1971 and 1987-1989 sought the capture of state power while the LTTE's protracted rebellion was aimed at secession. These armed insurgencies highlighted the fact that the Sri Lankan state needed reforms in a fundamental way. Quite importantly, the state successfully crushed the two JVP insurgencies by military means, but did not do much in terms of major policy reforms to open up the political system for the marginalized social groups who the JVP had mobilized in a radical, counter-state project. The response of the United Front (UF) regime of the 1970s to the first JVP uprising in 1971 was to nationalize foreign-owned plantation companies on the premise that strengthening the state sector of the economy was necessary to address the social problem of unemployment among the educated rural youth. This policy failed either to generate new employment opportunities or provide new economic impetus to the crisis-ridden rural economy, primarily due to the inability of the bureaucratic and corrupt state sector to act as a catalyst for reform. The responses to the protracted Tamil nationalist insurgency are no better. Although the Tamil rebellion highlighted the 
need to reform the Sri Lanka's unitary state in a manner that would grant some measure of regional autonomy and self-rule to the minorities, the initiative for political reforms did not emanate from Sri Lanka's political establishment. The pressure for state reform came from an external source, the Indian government. The system of Provincial Councils introduced in 1987, following the interstate accord signed by the Indian Prime Minister and the Sri Lankan President in July that year, constituted the basis for state reform as a policy measure towards addressing the minority demands for self-rule. Sri Lanka has not managed to introduce any new reformist policy measure with regard to the minority grievances, although the civil war had continued unabated.

Sri Lanka's half-hearted political reform process against the backdrop of the prolonged ethnic conflict has been commented initially by Wilson (1988), and later by de Silva (1998 a), de Votta (2004), Gosh (2003) and in an edited volume by Bastian (1994). Wilson, a leading political scientist in Sri Lanka who functioned as a political advisor to the President of Sri Lanka in the late 1970s and early 1980s, records the story of the process of centralization of state power amidst the growing secessionist challenge from the Tamil minority community. The title of the book, the Break-up of Sri Lanka, indicated the author's personal sense of despair amidst the failure of the regime which he served to acknowledge the sheer gravity of the looming crisis in Sri Lanka. De Silva (1998 a), another academic-turned policy advisor to the same regime which Wilson served, sees the explanation of the lack of progress in political reforms in the excessive polarization of ethnic politics. Gosh also documents how domestic political actors of Sri Lanka failed to achieve any progress in political accommodation in a backdrop of deep divisions within the political establishment. The persistence of this tendency has not been weakened despite the reform spaces emerged from time to time, as mapped out by Fernando (1999).

The volume edited by Bastian (1994) is one of the early attempts to examine critically the question of devolution and power-sharing in Sri Lanka which began in 1987. One critical feature of the devolution experience has been the resistance emerged within the Sinhalese society, the political establishment and the state apparatus, particularly the civil bureaucracy. Some of the essays in the volume (Jani de Silva, Shastri, Uyangoda: all in Bastian: 1994,) examine the resistance to devolution in relation to centripetal pressures associated with regime agendas, the majoritarian drift of the Sri Lankan state, and the limits of the constitutional discourse. Shastri's observation at the end of the chapter "The Provincial Council System in Sri Lanka: A Solution to the Ethnic Problem?" is worth repeating; "it seems that the $\mathrm{PC}$ system is here to stay, but as presently constituted, it does not provide a solution to the ethnic problem. Failing a peaceful political settlement, it seems that a solution is once more sought through military means" (Shastri, 1994:224). Meanwhile, Gosh in his Ethnicity Versus Nationalism: The Devolution Discourse in Sri Lanka (2003) 
too highlights the extreme difficulty in Sri Lanka in replacing the civil war with a political process that promotes pluralist democray.

A continuing tendency in Sri Lanka's politics during the ethnic civil war has been the failed attempts made by governments and as well civil society organizations to expand the scope of devolution as a framework attractive to Tamil nationalists to review the secessionist project. For example, the People's Alliance government of 1994 tried a constitutional reform package by proposing a semi-federalist constitutional option. While the LTTE rejected the PA government's devolution package, the opposition to enhanced devolution mobilized within the Sinhalese polity was so strong that the PA government ultimately abandoned the initiative. Resistance to state reform re-emerged during and after the 2002-2003 peace process as well. This raises a fundamental question about the capacity of the Sri Lankan polity to reform the state even when the state has been challenged by a protracted secessionist war. Uyangoda (2000) explores this contradiction in Sri Lanka by arguing that civil war itself has erased the political space for state reforms, notwithstanding the fact that the civil war was a product of the absence of major state reform initiatives in the pre-civil war period. Uyangoda shows that during the civil war and consequent to the intense ethnicization of political struggles and debates, the Sri Lankan state had become 'reform resistant' and 'unreformable.'

\section{Resilience or Crisis?}

Academic literature on Sri Lanka's experience of democracy can be divided into two broad approaches on the question of how to describe the continuity of parliamentary and liberal democracy in a recurring context of ethnic conflict, violence and civil war. The first approach celebrates the 'resilience' of Sri Lanka's democracy while the other sees democracy in a deep crisis.

K. M. de Silva's writings exemplify the perspective of resilience. In an essay written in 1998, de Silva concludes that the "strength of Sri Lanka's democracy" as well as its "capacity to recover from systematic violence" is the two-party system (de Silva, 1998 b:183). The systemic challenges that came from the Marxist Left as well as the radical Left could not replace the well-entrenched two-party system which in turn is firmly rooted in a relatively long history of electoral politics. In de Silva's explanation, the introduction of adult franchise in the early 1930s laid the foundation of Sri Lankan democracy that has proved itself "strong enough to survive political earthquakes which could have demolished less solidly constructed structures" (de Silva, 1998b:183). De Silva was obviously alluding to the fact that Sri Lanka did not produce a successful Marxist revolution or a right-wing military regime by overthrowing democracy.

Is the 'survival' and 'resilience' of electoral, parliamentary democracy a good enough reason to celebrate Sri Lanka's experience of democracy? The second perspective is skeptical about it. In a vast body of literature that has emerged on Sri Lanka's politics from the perspective of 
ethnic minorities, the key argument made is that Sri Lanka's parliamentary democracy has survived and taken deep roots in the form of an ethnic majoritarian democracy, that has systematically excluded meaningful power-sharing arrangements with the minorities (Manor: 1984, Tambiah: 1986, Wilson: 1988, Tiruchelvam: 2000). Electoral democracy and parliamentary democracy have also survived in a context of political and institutional decay as well as increasing authoritarianism (Moore: 1992, Krishna: 1999, De Votta: 2003 and 2004) and in illiberal forms. Elections have also been means to sustain regime authoritarianism (Warnapala and Hewagama: 1983). Some scholars have drawn attention to how the Sri Lankan state as well as society have been moving in the direction of militarization' (Uyangoda:1996, Haniffa: 2005). Unlike the resilience literature, this body of critical literature calls for substantial political reforms in order to make democracy more democratic as a way out of the continuing political crisis.

\section{Religion in the Democratic Process}

One key development that occurred in recent years in Sri Lankan politics is the entry of Buddhist monks into the electoral process. At the parliamentary elections held in April 2004, a newly formed political party, Jathika Hela Urumaya (JHU), fielded over 200 Buddhist monks as candidates. Ten of them were elected to parliament. They seem to play an influential role in shaping the policies of the present government, of which they are a constituent party. Their mandate, as they themselves see it, is to protect the interests of the Sinhalese-Buddhist majority ethnic community. In the broad political spectrum of the country, these political monks represent a particularly militant stream of Sinhalese nationalist mobilization. For those who study religion and politics in Sri Lanka, this represents a new development, because it seems to have altered the problematic of religion. The anthropological inquiry conventionally focused on the linkages between social change and religious transformation whereas the political scientists investigated how Buddhism became a political ideology, providing a framework of imagination and action for the majoritarian nationalist mobilization. Now, Buddhist political activism is no longer located outside the state institutions; it is no longer a 'civil society' enterprise. It is in the legislature and in other institutions of state power, shaping the state policy from within. It is also a part of Sri Lanka's 'normal' democratic politics.

How does Buddhist parliamentary politics relate itself to an agenda of ethnic conflict resolution, minority rights, and political pluralism which are integral to a broad process of democratic transformation? This question emerges urgently in view of the 'right-wing' political programme of the JHU which does not advocate minority rights on the basis of liberal equality, or the resolution of the ethnic conflict by political means. Quite interestingly, the direct participation of Buddhist monks in electoral and parliamentary politics cannot be interpreted as a sign of popular support for a theocratic 
state' in Sri Lanka. The State of Democracy Survey, conducted in 20042005, indicated that there is very little public support, even among the Buddhists, for the proposition that 'major decisions about the country should be taken by religious leaders, rather than politicians.' Only $5 \%$ of 4629 voters responded to the questions asked in this regard expressed 'strong support' while $16 \%$ indicated support. A high percentage of $41 \%$ disagreed and $16 \%$ strongly disagreed. Among the Buddhists, whose interests the monks claim to represent, strong support was just $2 \%$ and support was $16 \%$. The percentages for those who disagreed and strongly disagreed among the Buddhists were 47 and 13 respectively.

The scholarly literature on this 'new' Buddhist phenomenon has only begun to emerge in Sri Lanka. Degalle edited a volume in 2006 under the title, Buddhism, Conflict and Violence in Modern Sri Lanka (Degalle: 2006). This anthology claims to explore "the dilemmas that Theravada Buddhism faces in relation to the continuing ethnic conflict" in Sri Lanka (Degalle, 2006:1). One key dilemma of course is about the production and reproduction - "perpetuation," as the editor puts it - of violence in a Theravada Buddhist society while the Buddhist moral communities have not been able to present a transformatory way out from the conflict and civil war. In this larger context, Degalle examines the conditions under which Buddhist monks, under the organizational banner of the JHU, stormed into electoral politics (Degalle, 2006: 233-254). But this is only a preliminary work. The larger issue of Buddhist mobilization and democracy needs a deeper exploration.

\section{Women and Democracy}

On the question of women and democracy, Sri Lanka presents a paradox. Despite the relatively long history of electoral democracy, high rate of women's participation in the labour force, relatively high standards of social conditions for women, and women's presence at the highest level of political power as President and Prime Minister of the country, women's representation in parliament remains at a constantly low level of 5 percent. This figure has not changed since 1931 when the adult universal franchise was introduced. Women researchers have recognized this dilemma and attempted to explain it through surveys (Leitan: 2000, Jayawardena and Kodikara: 2003). Women's representation at provincial and local assemblies has also been quite low. In the provincial Councils, established in 1989, women's representation was 2. 9 percent. Ten years later, in 1989, it increased only marginally, to 3. 3 percent (Jayawardena and Kodikara, 2003:14).

What does the low level of women's representation indicate? Does it suggest that Sri Lanka's electoral democracy favours men over women? Or are there social-structural, cultural or ideological barriers to women's participation in competitive electoral politics? Or is it the case that representation in assemblies of governance only one indication of women's political participation? Is women activism in other spheres of political 
participation such as trade union politics, human rights and democratic struggles, also limited? Is patriarchy embedded in the democratic process itself? Answers to these questions require in-depth case studies as well as theorizing the actual existing democracy in Sri Lanka from a gender perspective.

In problematizing gender and democracy in Sri Lanka, the State of Democracy Survey of 2004-2005 highlights useful differences in the ways in which men and women in Sri Lanka relate themselves to democracy. In the index of support for democracy, Sri Lankan men are stronger democrats than women. While women recorded 33 percent as 'strong democrats', men recorded 38 percent. In the preference for democracy over dictatorship, men are 59 per cent while women are 48 percent. A similar pattern is observed in the preference for rule by elected representatives. While 47 percent of men preferred rule by elected representatives, only 40 percent women preferred that option. When asked how suitable democracy was to their country, 31 percent of men reported it to be very suitable. The corresponding percentage for women was 23. But on the satisfaction with democracy, both men and women in Sri Lanka reported more or less identical answers, five percent of both men and women reporting 'very satisfied' and 37 percent women and 39 percent men reporting 'satisfied.' Interestingly, more men (16 percent) are 'totally dissatisfied' with democracy than women (12 percent). These numbers seem to suggest that Sri Lanka's democracy does have a slightly male bias.

A theme that has generated an expanding body of writings on women in Sri Lanka is women and violence in a context of civil war. Three strands of inquiry seem to define the scholarship on this theme. The first is the subjection of women to violence in ethnic conflicts, nationalist mobilization and civil war (Jayawardena and de Alwis: 1996, Coomaraswamy: 2003, Thiruchandran: 1999). The second is militarization of gender (Maunaguru: 1995, Haniffa: 2005). The third is the question of women's agency in a context of the emergence of women militants and combatants (Coomaraswamy: 1996, de Mel: 1998, Rajasigham-Senanayake:2001). Two sets of arguments about the impact of the war and violence have provided the impetus for a debate among feminist scholars on the question of women's agency. Adel Ann of the LTTE argued that by joining the LTTE as a combatant, young Tamil women, who would have traditionally lived in a caste-defined and male-controlled, oppressive society, had achieved a measure of freedom - this breaking out of a "cycle of suffocating control" being a "refreshing expression and articulation of their new aspirations and independence" (Ann: 1993). Rajasingham-Senanayake looked at the question of women in civil war from a perspective of empowerment, even in conditions of tragedy and victimhood. In the armed conflict, women have suffered immensely; at the same time the losses they have suffered have compelled women to cross the "private/public barriers to contend with the military, to compete in the market and to survive economically." In the process, women have also gained "greater self-confidence and decision-making power" (Rajasingham- 
Senanayake, 2001: 108). Arguing against the current of the victimhood discourse, Rajasingham-Senanayake finds evidence among the displaced women, who headed households in the absence of the men, in 'refugee' camps a "sense of independence, empowerment and mobility." This is a specific kind of transformation which has taken place in extreme conditions of loss, displacement and vulnerability.

\section{Violence, Politics and Democracy}

Violence has been a dominant tendency in Sri Lanka's social and political life for decades. It is also intimately associated with the civil war and militarization. The JVP insurgency of 1971 and the state's military response to the insurgency was a major landmark in the emergence of violence as a mode of political practice, mediation and social control. The outbreak of ethnic violence in 1983 and the subsequent spread of the Tamil nationalist insurgency and the state's counter-insurgency war have been inter-inked processes of violence and counter-violence. The privileging of violence as a political practice by major political actors indicated how political struggles in Sri Lanka had moved away from the domain of democracy. The volume edited by Uyangoda and Biyanwila in 1997 under the title Matters of Violence, and its revised version of 2008, contain some key writings and mediations on the spread of violence as social and political practices. Some themes explored in this anthology are the human body, or the absence of it, in social practices of mourning and coping with terror (Sasanka Perera), hatred and revenge killings practices by Tamil insurgent groups in the context of the civil war (Purnaka de Silva), child soldiers and their place in the armed struggle (S. I. Keethaponcalan), impulses for violence in social relations (Geraldine Gamburd) and violence and gender. This volume also reflects on the issue of normalizing violence in a context where the Sri Lankan society has failed to interrogate the necessity of violence in the social and political life.

The deployment of violence in counter-state projects in Sri Lanka goes back to the early 1970s. The JVP rebellion of 1971 was the first organized expression of counter-state violence. It also gave rise to an expansive body of sociological and anthropological literature on the JVP and what came to be known as 'youth unrest' in Sri Lanka. Academics as much as policy makers were preoccupied with the question of why a violent outbreak of protest emerged in Sri Lankan society, which many had admired as a model of peace and democracy despite its poverty and social inequalities, so suddenly. The repetition of violence in the 1980s in two simultaneous counter-state rebellions - the Tamil secessionist war and the second JVP rebellion of 1987-1989 - reframed the question o political violence in terms of its persistence and almost cyclical reproduction. An arbitrary sample of the literature that has documented and explored both the counter-state and counter-insurgency violence and its social consequences includes Obeysekere (1984), Jani de Silva (1993 and 1998), Hettige (1992), Senaratne (1997), Matthews (1989), Moore (1993), Rampton (2003), Perera 
(1995 and 1999), and Daniel.(1997). A troubling issue about violence in Sri Lanka is not only its persistence, but also its seeming incorporation into the democratic process itself. This is particularly evident in the coexistence of civil war and democratic institutions in uneasy dialogue.

\section{New Themes for Research}

At present, research in Sri Lanka on themes related to democracy is concentrated in the areas of ethnic conflict, and political and constitutional reform. There is now an increasing body of literature on issues linked to the conflict, and peace-building as well as post-tsunami reconstruction. Researchers are also attracted to comparative research particularly on problems that combine conflict, peace-building and postdisaster reconstruction. However, democracy is not a key problematic in this research. This absence indeed opens up space for center-staging the democracy problematic under conditions of conflict transformation in a variety of ways.

Some of the key lacunae in Sri Lanka's social science research and literature in relation to democracy studies are s follows:

(i). The impact of continuing economic liberalization and reforms on the democratic process as well as on the institutions of democratic mediation is a theme that requires further exploration. This theme points to the important question of how the relative balance of power has been altered between the increasingly powerful, yet less representative 'executive' branch of the state and other representative organs of public governance such as the legislature, political parties and institutions of provincial and local governance. This is particularly relevant in view of the fact that oppositional mobilization for nearly thirty years has been towards reforming the state structure to a Westminster model of parliamentary governance. Interestingly, those who promote such reform projects while in the Opposition have abandoned the reform promise while in power. What is it that has made continuing centralization of state power attractive? Where does the explanation lie? In a systemic logic as proposed by Moore? In the specific culture of democratic politics that has combined ethnic mobilization and institutional decay, as suggested by De Votta? Is there a specific political economy of state that makes both economic liberalization and centralization of state power possible? What has the protracted civil war done to the politics of the state? These are questions that constitute the problematique of economy, society and the state in contemporary Sri Lanka.

(ii). The relationship between the post-liberalization political economy, the decline of the trade union movement and the rise of the 'social' sector is a theme the study of which will be useful to understand the ways in which Sri Lanka's state-society relations have been re-constituted. The basic theoretical question that needs exploration is whether this 'reconstitution' 
of state-society relations meant de-politicization of Sri Lanka's democratic process. Did it lead to a new condition of hollowed - out democratic politics, detaching democratic politics from the politics of class conflict, confining it largely to a relatively minimalist framework of electoral and 'delegative' politics?

(iii).The relationship between the new Buddhist mobilization, and electoral politics and its impact on the nature of public policy as well as the state is a key theme that needs to be explored in a series of in-depth studies. The following are some questions that require investigation: What does religious mobilization mean in defining the nature and forms of social mobilization for political power? Is democracy appropriating religion or is religion subsuming democracy? Is the new Buddhist mobilization further restricting the capacity of Sri Lanka's existing democracy to accommodate minority demands for equality and power sharing? Is Buddhist mobilization changing the nature of the Sri Lankan state and if so in what ways?

(iv). One major gap in the existing knowledge on the democracy in Sri Lanka is about how democracy works at the level of the community, at the very end of state power. The rich body of the political anthropological work does not provide insights into the actual working of democracy either. The existing political science literature is mostly about the functioning of local government institutions. Democracy beyond the local government institutions has hardly constituted a research interest among political scientists or political anthropologists. A set of relevant questions may be formulated as follows: What is the nature of the actually existing democracy on the ground, at the level of the communities? What is the role of political agents in the real life democratic politics? What do political agents do in the village setting in promoting party politics, party agendas, maintaining links between village people and politicians, maintaining patronage networks and re-distribution of public resources? Does local democracy function through a network of patron-client relations? What are the extra-democratic means through which democracy works on the ground?

(v). A significant development in recent Sri Lankan politics is the transformation of the composition as well as the nature of the 'political class.' At one level, the political class has become narrow in its range, particularly due to marginalization of the Tamil political elites from the domain of state power. At another level, there has been an expansion of the political class. This is specifically evident in the entry of the JVP and JHU into ruling coalitions. The JVP has earlier represented the interests of the subordinate and 'subaltern' classes, locating itself outside the 'system' through radical, insurrectionary mobilization. The JHU spearheads its political programme through activist Buddhist monks. Until 2004, they remained outside the ruling elite and now are activist members of the dominant political class. This change points to a set of interesting questions like the following: What 
are the changing dynamics of Sri Lanka's political class? Is the traditional concept of 'ruling class' adequate to capture the role being played by the JVP, Buddhist monks, the media, and small ideological groups in defining and even limiting state policies, policy priorities of governments, and statesociety relations? If it is not, how can we theorize the changing dynamics of the social bases of state power in contemporary Sri Lanka? What are the consequences of this change for Sri Lanka's democracy?

(vi). Sri Lanka's political science research is quite thin in understanding how social change has altered the social bases of political power. Increasing urbanization, demographic shifts, economic change and changes in the caste and class structures constitute the broad context that may have impacted on the nature of party competition, electoral behaviour, and bases of electoral support among political parties.

(vii) Theorizing the Sri Lankan probelamtique of gender and democracy requires in-depth studies of non-representational domains of women's political activism, mobilization and participation.

(viii). A major research gap continues to exist in relation to provincial and local governance and local democracy. Although there is a modest body of literature on the existing provincial council system, the body of knowledge it has produced needs updating, particularly because it has focused on the problems which devolution faced in the early phase of its institutionalization in the 1980s and the 1990s.

\section{Conclusions}

As this survey of literature suggests, the body of academic literature that deals with the issues of democracy in Sri Lanka has been multi-disciplinary. While the political science research on democracy has not been very strong, the gap has to some extent been filled by sociologists and anthropologists. The sociological and anthropological literature on how politics works on the ground, interacting with social structures, caste and class, religion and ethnic politics provides greater insights into how democracy works on the ground.

The discussion in this paper also shows that the scholarly agenda on Sri Lanka's society and politics during the past two decades has been largely set by the continuing ethnic conflict. The protracted ethnic conflict laid bare some of the major fault line in the country's society and politics. It pushed the anthropologists to re-focus their inquiry, the historians to examine issues of ethnicity, ideology and the historical processes of nationformation, and the literary critics to examine issues of identity politics. The political science work has also been responding to the ethnic conflict, but the range of issues examined in that body of work is not very wide. The political science research agenda has been limited to explaining the institutional dimensions of the conflict and possible 'solutions.' 
A key question that emerges from the discussion of this paper is about the absence of a strong body of political science research on questions of democracy in Sri Lanka. One explanation is that Sri Lankan academics, like its citizens, have taken democracy for granted. Sri Lanka has not experienced a major political struggle for democracy. Modern parliamentary and electoral democracy was introduced to Sri Lanka during the British colonial rule without a major social movement for democratization. It was literally a reform from above. Sri Lanka's process of democratization has been a relatively painless process and gradually parliamentary democracy took strong institutional roots. Quite paradoxically, during the postcolonial years the democracy struggle took place among the minority ethnic communities. Struggles for civil and political rights have not been in the mainstream of politics. The body of knowledge on the human rights issues is largely confined to reports and documentation. This situation calls for more in-depth studies on the trajectories of democracy in Sri Lanka as defined by ethnic majoritarianism, protracted civil war, macro-economic liberalization and the continuity of institutionalized forms of democracy. These efforts need to be accompanied by theoretically informed studies on concrete processes of change at both macro and ground levels. 


\section{References}

Abeysekara, Ananda, 2002, Colors of the Robe: Religion, Identity and Difference, Columbia, South Carolina: University of South Caolina Press.

Amarasinghe, Y. Ranjith, 1998, Revolutionary Idealism and Parliamentary Politics: A Study of Trotskyism in Sri Lanka, Colombo: Social Scientists' Association.

Amaratunga, Chanaka (ed.), 1989, Ideas for Constitutional Reform, Colombo: Council for Liberal Democracy.

Ann, Adel, 1993, Women Fighters of Liberation Tigers, Jaffna.

Bastian, Sunil (ed.), 1994, Devolution and Development in Sri Lanka, New Delhi: Konark Publishing Ltd.

Bastian, Sunil and Luckham, Robin, (eds.), 2003, Can Democracy be Designed? The Politics of Institutional Choice in Conflict-torn Societies, London \& New York: Zed Books.

Coomaraswamy, Radhika, 1996, "Tiger Women and the Question of Women's Emancipation," Pravada, Vol. 4, No. 9, pp. 8-10.

Coomaraswamy, Radhika, 2003, "The Politics of Institutional Design: An Overview of the Case of Sri Lanka," in Bastian, Sunil and Luckham, Robin, (eds.), pp. 120-137.

Coomaraswamy, Radika, 2003, "A Question of Honour: Women, Ethnicity and Armed Conflict," in Wenona Giles et al (eds.), Feminists Under Fire: Exchanges Across War Zones, Toronto: Between the Line, pp. 91-102.

Daniel, Valentine, 1997, Chapters in an Anthropology of Violence: Sri Lankans, Sinhalas and Tamils, Delhi: Oxford University Press.

De Mel, Neloufer, 1998, "Agent or Victim? The Sri Lankan Woman Militant in the Interrugnam," in Micheal Roberts (ed.), Sri Lanka: Collective Identities Revisited, Volume II, Colombo: Marga Institute, pp. 199-220.

De Silva, Jani, 1993, “The Ethics of Struggle: Changing Political Perceptions among Secondary school Students in a Southern Sri Lankan Electorate," in Ulrich Everding (ed.), Problems of Democracy, Constitutionalism and Political Violence, Colombo: Goethe Institute, pp. 73-18.

De Silva, Jani, 1994, "Centripetal Pressures and Regime Change in the Post-colonial Sri Lankan State," in Sunil Bastian (ed.), Devolution and Development in Sri Lanka, New Delhi: Konark Publishing Ltd, pp. 34-82.

De Silva, Jani, 1998, Praxis, Language and Silence: The July 1987 Uprising of the JVP in Sri Lanka," in Michael Roberts (ed.), Sri Lanka: Collective Identities Revisited, Volume II, Colombo: Marga Institute, pp. 163-198.

De Silva, K. M. 1998 a, Reaping the Whirlwind: Ethnic Conflict, Ethnic Politics in Sri Lanka, London and New Delhi: Penguin Books. 
De Silva, K. M. 1998 b, "Sri Lanka: Electoral Politics and the Resilience of Democracy," in John m. Richardson Jr. and S. W. R. de a Samarasinghe, 1998, Democratisation in South Asia: The First Fifty Years, Kandy, Sri Lanka: International Center for Ethnic Studies, pp. 163-186.

Degalle, Mahinda, (ed.), 2006, Buddhism, Conflict and Violence in Modern Sri Lanka, London and New York: Routledge.

Degalle, Mahinda, "JHU Politics for Peace and a Righteous State" in Degalle, Mahinda, (ed.), 2006, Buddhism, Conflict and Violence in Modern Sri Lanka, London and New York: Routledge, pp. 433-254.

DeVotta, Neil, 2002, 'Illiberalism and Ethnic Conflict in Sri Lanka,' Journal of Democracy, Vol. 13, No. 1, pp. 84-98.

DeVotta, Neil, 2006 "From Ethnic Outbidding to Ethnic Conflict: The Institutional Bases for Sri Lanka's Separatist War," in P. Sahadevan and Neil DeVotta (eds.), Politics of Conflict and Peace in Sri Lanka, New Delhi: Manak Publications, pp. 3-29.

DeVotta, Neil, 2003 b, "Sri Lanka's Political Decay: Comparing the October 2000 and December 2001 Parliamentary Elections,' Commonwealth and Comparative Politics, Vol. 41, No. 2, pp. 115142.

DeVotta, Neil, 2004, Blowback, Linguistic Nationalism, Institutional Decay and Ethnic Conflict in Sri Lanka, Stanford: Stanford University Press.

Edrisinha, Rohan, 1993, "The Case for a Federal Constitution," in Rohan Edrisinha and Jayadeva Uyangoda (eds.), Essays in Constitutional Reform, Colombo: University of Colombo.

Fernando, Laksiri, 1999, "Three Phases of Political Development after Independence," in W. D. Lakshman and C. A. Tisdel (eds.), Facets of development of Sri Lanka Since Independence: Socio-Political, Economic, Scientific and Cultural, Queensland: The University of Queensland, pp. 109-132.

Gamburd, Geraldine, 1997, "Understankding Terrorism: Culture and Sharing - An Essential Relationship," in Matters of Violence: Reflections on social and Political Violence in Sri Lanka. Uyangoda, Jayadeva and Janika Biyanwila (eds.), Colombo: Social Scientists' Association.

Goonathilake, Susantha, 2006, Recolonisation: Foreign Funded NGOs in Sri Lanka, New Delhi: SAGE.

Gosh, Partha, 2003, Ethnicity versus Nationalism: The Devolution Discourse in Sri Lanka, New Delhi: SAGE.

Gunasinghe, Newton, 2001, Selected Essays, Colombo: Social Scientists' Association.

Gunasekera, Tamara, 1994, Hierarchy and Egalitarianism: Caste, Class and Power in Sinhalese Peasant Society, London: The Athlone Press.

Haniffa, Farzana, 2005, "Sri Lanka: Ethnic Conflict, Post-Colonial Nation- 
Building and Militarisation," in Jayadeva Uyangoda, (ed,), Militarising State, Society and Culture in Asia, Critical Perspectives, Hong Kong: ARENA.

Hellmann-Rajanayagam, Dagmar, 1994, The Tamil Tigers' Armed Struggle for Identity, Stuutgart.

Hettige, S. T. 1984, Wealth, Power and Prestige: Emerging Patterns of Social Inequality in a Peasant Context [in Sri Lanka], Nugegoda: Dept. of Sociology, University of Sri Jayawardenapura.

Hettige, S. T. 1992, Unrest or Revolt?, Colombo: Goethe Institute.

Jayantha, Dilesh, 1992, Electoral Allegiance in Sri Lanka, South Asian Studies 48, Cambridge: Cambridge University Press.

Jayasekara, P. V. J. and Amarasinghe, Ranjith, 1987, "The Economy, society and Polity from Independence to 1977," in David Dunham and Charles Abeysekera (eds.), 1987, Essays on the Sri Lankan Economy, Colombo: Social Scientists' Association.

Jayawardane, Amal, (ed.), 2007, Perspectives on National Integration in Sri Lanka, Colombo: National Integration Planning Unit.

Jayawardena Kishali Pinto and Kodikara, Chulani, 2003, Women and Governance in Sri Lanka, Colombo: International Centre for Ethnic Studies.

Jayawardena, Kumari and Malathi de Alwis, 1996, Embodied Violence, Communalising Women's Sexuality in South Asia, New Delhi: Kali for Women.

Jiggins, Janice, 1979, Caste and Family in the Politics of the Sinhalese 1941.1976, Cambridge: Cambridge University Press.

Jupp, James, 1978, Sri Lanka Third World Democracy, Colombo: K. V. G de Silva and Sons.

Kapferer, Bruce, 1983, A Celebration of Demons, Bloomington: Indiana University Press.

Kapferer, Bruce, 1988, Legends of People, Myths of State, Washington: Smithsonian Institution Press.

Kearney, Robert N, 1967, Communalism and Language in the Politics of Ceylon, Durham, NC: Duke University Press.

Kearny, Robert N, 1973, The Politics of Ceylon (Sri Lanka), Ithaca: Cornell University Press.

Krishna, Sankaran, 1999, Postcolonial Insecurities: India, Sri Lanka and the Question of Nationhood, Minneapolis and London: University of Minnesota Press.

Leach, Edmund, 1961, Pul Eliya, A Village in Ceylon, Cambridge: Cambridge University Press.

Leitan, Tressie, 2000, "Women in Political Participation and Decision Making," in CENWOR, Post-Beijing Reflections: Women in Sri Lanka 1995-2000, Colombo: CENWOR.

Lersky, George Jan 1964, History of Trotskyism in Ceylon, A Documentary History of the Lanka Sama Samaja Party, Stanford: Stanford University Press. 
McGilvray, D. B. (ed.), 1982, Caste, Ideology and Interaction, Cambridge University Press.

Manogaran, C and B. Pfafenberger (eds.), 1994, The Sri Lankan Tamils: Ethnicity and Identity, Boulder, CO: Westview Press.

Manor, James, (ed.), 1984, Sri Lanka: in Change and Crisis, London: Croom Helm.

Mathews, Bruce, 1989, "The Janatha Vimukthi Peramuna and the Politics of the Underground in Sri Lanka,' Roundtable 312, pp. 425-439.

Maunaguru, Sitralega, 1995, "Gendering Tamil Nationalism: The Construction of "Woman" in Projects of Protest and Control," in Pradeep Jeganathan and Quadri Ismail (eds.), Unmaking the Nation: Politics of Identity and History in Modern Sri Lanka, Colombo: Social Scientists' Association, pp. 158-175.

Moore, Mick, 1990, "Economic Liberalization Vs. Political Pluralism in Sri Lanka," Modern Asian Studies, Vol. 24, No. 2, (May 1990), pp. 341-383.

Moore, Mick, 1992, "Retreat from Democracy in Sri Lanka," Journal of Commonwealth and Comparative Politics, No. 30, pp. 70-84.

Moore, Mick, 1993, "Thoroughly Modern Revolutionaries: the JVP in Sri Lanka," Modern Asian Studies, No. 27, pp. 593-642.

Obeysekere, Gananath, 1967, Land Tenure in Village Ceylon, Cambridge: Cambridge University Press.

Obeysekere, Gananath, 1970, "Religious Symbolism and Political Change in Ceylon," Modern Ceylon Studies, Vol. 1, pp. 48-63.

Obeysekere, Gananath, 1984, "The Institutionalization of Political Violence and the Dismantling of Democracy in Sri Lanka," in Sri Lanka: Myths and Realities, Colombo: Centre for Rational Development.

Obeysekere, Gananath, 1995, "Buddhism, Nationhood and Cultural Identity: A Question of Fundamentals," in M. E. Marty and R. S. Appelby (eds.), Fundamentalism Comprehended, Chicago: University of Chicago Press, pp. 231-256.

Peiris, Ralph, 1956, Sinhalese Social Organization; Colombo: University of Ceylon Press.

Perera, Sasanka, 1995, Living with Torturers and Other Essays of Intervention: Sri Lankan Society, Politics and Culture in Perspective, Colombo: International Center for Ethnic Studies.

Perera, Sasanka, 1999, Stories of Survivors: Socio-Political Contexts of Female Headed Households in Post-Terror Southern Sri Lanka, Colombo: Women's Education and Research Center.

Pfaffenberger, Brian, 1982, Caste in Tamil Culture: The Religious Foundations of Sudra Domination in Tamil Sri Lanka, Syracuse: Syracuse University Press.

Phadnis, Urmila, 1976, Religion and Politics in Sri Lanka, London: C. Hurst. Phadnis, Urmila, 1989, "Sri Lanka: Crisis of Legitimacy and Integration" in Larry Diamond, Juan Linz and Seymour Martin Lipset (eds.), Democracy in Asia, New Delhi: Vistaar Publications. 
Ponnambalam, S, 1981, Dependent Capitalism in Crisis: the Sri Lankan Economy 1948-1980, London: Zed Press.

Rajasingham-Senanayake, Darini, 2001, "Ambivalent Empowerment: The Tragedy of Tamil Women in Sri Lanka," in Rita Manchanda (ed.), Women, War and Peace in South Asia, New Delhi: SAGE, pp. 102-130.

Rajasingham-Senanayake, Darini, 1999, "Democracy and the Making of Bi-Polar Ethnic Identity," in J. Pfaff-Czarnecka et al (eds.), Ethnic Futures: the State and Identity Politics in Asia, New Delhi: SAGE.

Rampton, David, 2003, "Sri Lanka's Many Headed Hydra: The JVP, Nationalism and the Politics of Powerty," in CEPA, Politics of Poverty in Sri Lanka, Colombo: CEPA.

Robert. Michael (ed.), 1979, Collective Identities, Nationalisms and Protests in Modern Sri Lanka, Colombo: Marga Institute.

Roberts, Michael, 1978, "Ethnic Conflict in Sri Lanka and Sinhalese Perspectives: Barriers to Accommodation," in Modern Asian Studies, Vol. 12, No, 3, pp. 353-376.

Robinson, Margaret, 1975, Political Structure in a Changing Sinhalese Village, Cambridge: Cambridge University Press.

Ryan, B, 1953, Caste in Modern Ceylon, The Sinhalese System in Transition, New Brunswick, NJ: Rutgers University Press.

Samaranayake, Gamini, 2008, Political Violence in Sri Lanka 1071-1987, New Delhi: Gyan Publishers.

Scott, David, 1992, "The Demonology of Nationalism: On the Anthropology of Ethnicity and Violence in Sri Lanka," Economy and Society, Vol. 19, No. 4, pp. 492-510.

Scott, David, 1994, Formation of Ritual: Colonial Anthropological Discourses and the Sinhala Yaktovil, Minnesota: Minnesota University Press.

Senaratne, J. P. 1997, Political Violence in Sri Lanka 1997-1990: Riots, Insurrections, Counterinsurgencies and Foreign Intervention, Amsterdam: VU University Press.

Seneviratne, H. L. 1999, The Work of Kings: The New Buddhism in Sri Lanka, Chicago: Chicago University Press.

Shastri, Amita, 1994, The Provincial Council System in Sri Lanka: A Solution to the Ethnic Problem?" in Sunil Bastian (ed.) Devolution and Development in Sri Lanka, New Delhi: Konark Publishing Ltd, pp. 198-226.

Spencer, Jonathan, 1990 a, A Sinhala Village in a Time of Trouble, Politics and Change in Rural Sri Lanka, Delhi: Oxford University Press.

Spencer, Jonathan, 1990 b, "Writing Within: Anthropology, Nationalism and Culture in Sri Lanka," Current Anthropology, Vol. 31, No. 3, pp. 283-300.

Spencer, Jonathan, 1997, Anthropology, Politics and the State: Democracy and Vioelnce

State of Democracy in South Asia, A Report, 2008, New Delhi: Oxford University Press. 
Stirrat, R. L. 1982, "Caste Conundrums: Views of Caste in Sinhalese catholic Village," in D. B. McGilvray (ed.), Caste Ideology and Interaction, Cambridge; Cambridge University Press.

Stokke., Kristian, 2006, "Building the Tamil Eelam State: Emerging State Institutions and Forms of Governance in LTTE-Controlled Areas in Sri Lanka," in Third World Quarterly, 27:6, pp. 1021-1040.

Tambiah, S. J. 1986, Sri Lanka: Ethnic Fratricide and Dismantling of Democracy, Delhi: Oxford University Press.

Tambiah, S. J. 1992, Buddhism Betrayed? Religion, Politics and Violence in Sri Lanka, Chicago: Chicago University Press.

Thiruchandran, Selvi, 1999, The Other Victims of War: Emergence of Female-Headed Households in Eastern Sri Lanka, New Delhi: Vikas Publishing House.

Tiruchelvam, Neelan, 2000, The Politics of Federalism and Diversity in Sri Lanka," in Ghai, Yash (ed.), 2000, Autonomy and Ethnicity, Negotiating Competing Claims in Multi-Ethnic States, Cambridge: Cambridge University Press, pp. 197-215.

Uyangoda, Jayadeva, 1996, "Militarization, Violent State, Violent society, Sri Lanka," in Kumar Rupesinghe and Khawar Mumtaz (eds.), 1996, Internal Conflicts in South Asia, London and New Delhi: SAGE, pp. 118-130.

Uyangoda, Jayadeva, 2000, "A State of Desire? Some Reflections on the Unreformability of Sri Lanka's Post-Colonial Polity," in S. T. Hettige and Markus Mayer (eds.), Sri Lanka at Crossroads, Dilemmas and Prospects after 50 Years of Independence, New Delhi: Macmillan, pp. 92-118.

Uyangoda, Jayadeva, 2001, Questions of Sri Lanka's Minority Rights, Colombo: International Center for Ethnic Studies.

Uyangoga, Jayadeva, 2007, "Power-Sharing and Autonomy rights of 'Minority' Communities in Sri Lanka,"in Jayawardane, Amal, (ed.), 2007, Perspectives on National Integration in Sri Lanka, Colombo: National Integration Planning Unit, pp.43-55.

Uyangoda, Jayadeva and Janaka Biyanwila (eds.), 1997, Matters of Violence: Reflections on Social and Political Violence in Sri Lanka, Colombo: Social Scientists' Association.

Warnapala, W A. Wiswa and Hewagama, L. Dias, 1983, Recent Politics in Sri Lanka: The Presidential Election and the Referendum of 1982, A Study of Electoral Practice and Behaviour in an Asian Democracy, New Delhi: Navrang.

Wickramaratne, Jayampathy, 2007, "Power-Sharing Plus: The Only Way Forward" in Jayawardane, Amal (ed.), Perspectives on National Integration in Sri Lanka, Colombo: NIPU, pp. 92-100.

Wickramasinghe, Nira, 2001, Civil Society in Sri Lanka, New Circles of Power, New Delhi: SAGE Publications.

Wilson, A. J. 1974, Politics in Sri Lanka 1947-1973, London: Macmillan. 
Wilson, A. J. 1975, Electoral Politics in an Emergent State, London: Cambridge University Press.

Wilson, A. J, 1988, The Break-up of Sri Lanka: The Sinhalese-Tamil Conflict, London: Croom Helm.

Wilson, A. J. 2000, Sri Lankan Tamil Nationalism: Its Origins and Development in the $19^{\text {th }}$ and $20^{\text {th }}$ Centuries, London: Penguin.

Woodward, Calvin, A, 1969, The Growth of a Party System in Ceylon, Providence, Rhode Island: Brown University Press.

Wriggins, Howard, 1960, Dilemmas of a New Nation, Princeton: Princeton University Press.

Yalman, Nur, 1967, Under the Bo Tree, Berkeley and LA: University of California Press. 